WHEN President Nixon abolished the Office of Science and Technology last year, thereby ending 15 years of scientific presence in the White House, his action was greeted with a predictable flood of complaints from the scientific community and rumblings of discontent have continued ever since. Now the National Academy of Sciences, the most prestigious scientific body in the United States, has taken to print to deplore the banishment of scientists from the corridors of power and to urge that they be restored through the establishment of a Council for Science and Technology in the White House.

The idea is neither new nor particularly startling, but the fact that it has come from the academy has accorded it considerable attention, particularly on Capitol Hill. The proposal is, essentially, for a three-member council to be established to help in dividing the budgetary pie for science and technology, to provide independent analyses of military research and development programmes and to have a strong input into foreign and domestic science policymaking.

When Nixon scrapped the Office of Science and Technology (OST) by executive fiat in January last year, he also designated Dr H. Guyford Stever, Director of the National Science Foundation, as science adviser-a position previously occupied by the Director of OST. Stever, who is head of one of the smaller scientific agencies in the federal landscape, was, however, given no authority to advise on military research and development--which accounts for more than half of the federal science budget-because "the Department of Defense has strong capabilities for assessing weapons needs". And he was also told to report to the President through Dr George Shultz, who was then Nixon's adviser on economic affairs.

Although Stever has generally been credited with doing a commendable job, given the limit to his powers, the fact that the science advisory apparatus was shifted from the White House to a relatively obscure part of the federal bureaucracy rankled considerably among members of the scientific establishment. And it did not help matters much when Nixon, seeking advice on energy research and development, turned not to Stever but to Dr Dixy Lee Ray, chairman of the Atomic Energy Commission. Since that was perhaps the most important exercise in science policymaking last year, the fact that Stever was seemingly overlooked when the task was assigned suggested that Nixon was not paying much attention to the science policy machinery that he had established.

Central to the complaints that have

\section{Scientists want a foot in the White House}

\author{
by Colin Norman, Washington
}

been raised about the new arrangements for science policy is that although Stever may be an able man, and although he has established an office to provide staffwork on policy questions, the fact that he is not in the White House puts him in a weak position to orchestrate the federal government's scientific activities, which are scattered over numerous different agencies and departments. The White House is the place where interagency disputes are settled, where coordination of programmes takes place and, most important, where final decisions on the Administration's budget are taken. Thus, the argument goes, for scientific advice to be effective it must come from a White House office.

That, in short, is the reasoning behind the academy's proposal for a Council for Science and Technology. The proposal, which was released during Congressional hearings last week recommends the following features for the Council for Science and Technology:

- It would consist of at least three people, appointed by the President; it would have a small staff, and it would be able to call upon consultants and panels of outside scientists for advice. - The council would establish strong links with the three chief policymaking organisations in the White House-the Domestic Council, which provides coordination and policy guidance for a range of domestic programmes, the National Security Council, which does the same for defence matters, and the Office of Management and Budget, which holds the purse strings for all government departments and agencies. The academy suggests that the chairman of the Council for Science and Technology should sit on the Domestic Council, since that body must deal with "a substantial number (of policies and problems) which involve components of science and technology". Arrangements with the National Security Council would be more informal, but participation by the proposed Council for Science and Technology in defence policymaking would at least rectify one of the major deficiencies in the present science policy system-lack of independent scrutiny of Defense Department programmes. As for the Office of Management and Budget, that body establishes priorities among federal programmes and agencies through the annual budget. Thus, the academy argues, it is essential that it be provided with strong input from the scientific community in its deliberations over the federal government's $\$ 20,000$ million science budget.

- Finally, the academy recommends that the proposed council should deliver an annual report on major developments in science and technology. In fact, OST did attempt to produce such a report during its last year of life, but the effort was eventually dropped partly because it engendered considerable opposition from some sectors of the government.

Nowhere in its report does the academy say outright that the present system is not working properlyindeed, at one point, the report says that "we view with admiration the efforts of the Director of the National Science Foundation"-but implicit in its argument is that the arrangement just cannot cope with many of the problems with which it has to deal, simply because it is one step removed from the centre of power. But a fundamental question is whether any science advisory apparatus can be made to work in an Administration which has not so far shown much enthusiasm for science advice. The OST arrangement, for example, even though it was at the centre of power, lost considerable influence during the later stages of its life, partly because PSAC made some public recommendations which were diametrically opposed to Administration policy - a prime example being a report opposed to development of the SST which was made public when the Administration was fighting Congress to get approval for the SST programme.

Nevertheless the Academy's proposals met with a warm reception on Capitol Hill, for last week Senators Frank Moss and Warren Magnuson proposed a bill which would create a Council of Advisers on Science and Technology in the White House. Hearings wil be held on the measure on July 11 by the Senate Committee on Aeronautical and Space Sciences and the Senate Committee (which Moss and Magnuson, respectively, chair) and there is a good chance that the Senate will endorse the proposal by the end of the year. But the House of Representatives is unlikely to move that quickly. The Committee on Science and Astronautics is now in the middle of a protracted study of the national science policy machinery, and although the Academy's recommendations went down well with the committee, it is unlikely that it will be ready to suggest changes in the machinery in time for the House to act this year. But there is every chance that Congress will act next year to reestablish a White House science policy office, in which case no President would be able to get rid of it without congressional approval. 